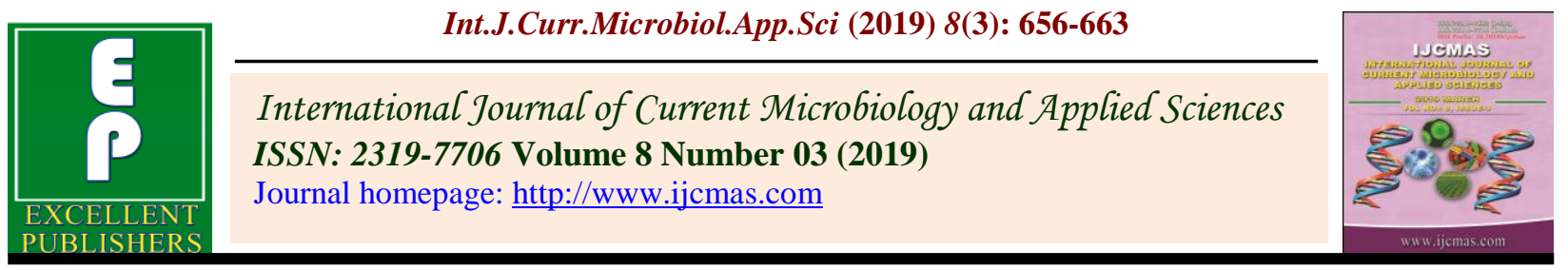

Original Research Article

https://doi.org/10.20546/ijcmas.2019.803.081

\title{
Entrepreneurial Behaviour of Flower Growers in Tumkur District of Karnataka State
}

\author{
N. Bindu*, Y.N. Shivalingaiah and N.V. Shwetha \\ Department of Agricultural Extension, UAS, GKVK, Bengaluru - 560 065, Karnataka, India \\ *Corresponding author
}

\begin{tabular}{l} 
K e y w o r d s \\
Entrepreneurial \\
behaviour, \\
Innovativeness, Decision \\
making ability, \\
Achievement motivation, \\
Knowledge about \\
farming enterprise, Risk \\
orientation, Ability to co- \\
ordinate farm activities, \\
Information seeking \\
Behaviour, Economic \\
motivation, Leadership \\
ability, Scientific \\
orientation and \\
Management orientation \\
\hline Article Info \\
\hline Accepted: \\
07 February 2019 \\
Available Online: \\
10 March 2019
\end{tabular}

Keywords

Entrepreneurial behaviour,

making ability,

Knowledge about

ordinate farm activities,

Information seekin

motivation, Leadership

ability, Scientific

Management orientation

Article Info

Accepted:

\section{Introduction}

India is predominantly an agriculture based country. Almost two third of the population in India depends on agriculture for their livelihood. It has become the main source of income. In rural India, it is the largest provider for the livelihood of people. Agriculture is
The study was conducted during the year 2017-18 in Tumkur district of Karnataka state to measure the entrepreneurial behaviour of flower growers. In Tumkur district, Madhugiri taluk was purposefully selected for the study, since it is dominated with the major flower growing areas. Four villages of Madhugiri taluk were considered for the research purpose and forty chrysanthemum, forty jasmine and forty crossandra growers were selected randomly from each of the village. Thus, leading to the total sample size of 120 . To quantify the entrepreneurial behaviour of flower growers, eleven dimensions like innovativeness, decision making ability, risk orientation, achievement motivation, knowledge of farming enterprise, ability to co-ordinate farm activities, information seeking behaviour, economic motivation, leadership ability, scientific orientation and management orientation were considered. Exactly half $(50.00 \%)$ of the chrysanthemum growers, 37.50 per cent of jasmine growers and about two-fifth $(42.50 \%)$ of the crossandra growers were observed to possess medium level of entrepreneurial behavior. With respect to overall entrepreneurial behaviour of the flower growers, more than two-fifth $(43.34 \%)$ of them falls under medium category. When comes to dimensions wise distribution of flower growers in total, significant percentage of them belongs to low category of ability to coordinate farm activities (37.50 \%) and leadership ability (46.66 \%), medium category of decision making ability (44.16\%), knowledge on farming enterprise (45.83\%), risk orientation $(36.66 \%)$, economic motivation $(49.00 \%)$, scientific orientation $(51.66 \%)$ and management orientation (41.66 \%), high category of innovativeness (35.83\%), achievement motivation (43.33\%), and information seeking behavior (44.16\%). 
national economy. Though there is a decline in the share of agriculture to India's GDP, its contribution is significance in total country's GDP. Despite declining agriculture share in the economy, majority of rural workforce continue to depend on agriculture for employment.

Horticultural crops have improved economic condition of farmers because of higher returns from many perennial flower crops, plantation crops, seasonal availability of fruits and vegetables throughout the year. Growing horticultural crops has been recognized as an ideal option for the improvement of livelihood security, attaining income and food security, enhancing employment generation and increasing income through value addition. It has also played a crucial role in women endowment, as it provides employment opportunities in vegetable production, floriculture, mushroom cultivation etc.

Floriculture is regarded as an age old farming activity in India possessing immense potential to generate gainful self-employment and entrepreneurship among small and marginal farmers. After liberalization, floriculture was identified as a sunrise industry in India. The liberalization of trade and industrial policies had led to the development of export oriented cut flower production. Because of the new seed policy, it is also possible to import the planting material and seeds of international varieties.

Rural development is more than ever before linked entrepreneurship. It plays a key role in economic development of the country. Entrepreneurship stands as a vehicle to improve the quality of life for individuals, families and communities and to sustain a healthy economy and environment.

Entrepreneurship can be taken up in a wide range of fields like Business, Agriculture,
Horticulture, Education, Dairy Industry, Social Works etc. Scientific and advanced agriculture is mainly based on capital investment and output. Hence, it also requires entrepreneurship. In developing countries like India, the role played by entrepreneurs is of great importance. Thus in all developmental activities more attention should be given to the entrepreneurship development.

The entrepreneurial behaviour is a crucial and indispensable factor for the growth of Horticulture farming. Development of any nation's economy primarily depends on the main role played by entrepreneurs. A considerable amount of research about the personal traits and behaviour of entrepreneurs have been conducted in recent years. But, the precise identification of entrepreneurial talent remains elusive. Thus, considering the importance of entrepreneurship and role played by the entrepreneurs in the horticultural growth and development, the study intended to measure the entrepreneurial behaviour of flower growers.

\section{Materials and Methods}

The investigation was carried out in Tumkur district of Karnataka, during the year 2017-18 to study the entrepreneurial behaviour of flower growers. In Tumkur district, Madhugiri taluk was purposefully selected for the study by recognizing the importance of the floriculture as an income and employment generating activity in the taluk. The top four villages which have the highest area under flower cultivation were selected from the taluk. Then, from each village, 40 chrysanthemum, 40 jasmine and 40 crossandra growers were picked randomly. Thus, the total number of the respondents considered for the study was 120. Ex-post facto research design was employed in the present study. Data was collected by using a detailed pre tested interview schedule and employed personal 
interview method. The responses were scored, quantified, categorized and tabulated using statistical methods like percentage, mean, standard deviation and frequencies.

\section{Results and Discussion}

\section{Overall entrepreneurial behaviour of flower growers}

Table 1 indicates the overall entrepreneurial behaviour of flower growers. Among chrysanthemum growers, half $(50.00 \%)$ of them possess medium entrepreneurial behaviour followed by high $(30.00 \%)$ and low $(20.00 \%)$. Among the jasmine growers, 37.50 per cent, 32.50 and 30.00 per cent belongs to medium, high and low categories respectively. About two-fifth $(42.50 \%)$ of the crossandra growers show medium entrepreneurial behaviour followed by low (32.50\%) and high $(25.00 \%)$. With respect to overall entrepreneurial behavior of the flower growers, more than two-fifth $(43.34 \%)$ of them falls under medium category followed by high $(29.16 \%)$ and low $(27.50 \%)$ entrepreneurial behaviour group. The reason for medium entrepreneurial behaviour of farmers might be due to the fact that study area is more suitable for flower cultivation. The other reason also might be that significant association was found between education, occupation, land holding, annual family income, extension participation, mass media participation, self-reliance, cosmopoliteness and deferred gratification with entrepreneurial behaviour of the flower growers.

Entrepreneurial behaviour component wise distribution of flower growers

\section{Innovativeness}

The Table 2 indicted that, more than one-third $(37.50 \%)$ of the chrysanthemum growers have high innovativeness followed by medium
$(32.50 \%)$ and low (30.00\%) innovativeness. Among the jasmine growers, 45.00 per cent, 32.50 per cent and 22.50 per cent belonged to high, medium and low innovativeness category. Slightly less than half $(47.50 \%)$ of the crossandra growers belonged to low innovativeness followed by medium $(27.50 \%)$ and high innovativeness $(25.00 \%)$ category. The flower growers possess high innovativeness $(35.83 \%)$ followed by low $(33.33 \%)$ and medium $(30.83 \%)$ innovativeness. The trend might be due to the fact that innovative flower growers usually have more favourable attitude towards adoption of new technologies, while medium innovativeness is due to moderate participation of flower growers in extension activities and mass media programmes. However, low innovativeness might be due to fact that flower growers wait for other members in his social system to adopt the innovation and achieve success and also their poor economic condition might have prevented them to adopt new innovations.

\section{Decision making ability}

It is evident from the Table 2 that, slightly less than half $(47.50 \%)$ of the Chrysanthemum growers belonged to medium decision making ability category. Whereas, 35.00 and 17.50 per cent of them belonged to high and low decision making ability categories, respectively. Among the Jasmine growers $40.00,32.50$ and 27.50 per cent belonged to medium, low and high decision making ability category. More than two-fifth (45.00\%) of the Crossandra growers have medium decision making ability followed by low $(37.50 \%)$ and high decision making ability (17.50 \%). Decision making in farming, especially in Indian conditions is very difficult due to gambling monsoons and lack of stabilized price policy. On the whole, the flower growers have medium decision making ability (44.16 $\%)$ followed by low $(29.16 \%)$ and high 
decision making ability (26.66\%). Decision making ability is based on the foresight and confidence of an individual. The reason for the above fact is that majority of flower growers are middle aged, who has comparatively free hands in making decisions about to adopt or reject the innovation. Other plausible reason might be their flower cultivation experience which helped them to choose right decision at right time and at right place. These factors might have facilitated the flower growers to make wise decisions among available alternatives.

\section{Achievement motivation}

The results in Table 2 also indicated that, 37.50 per cent of chrysanthemum growers were having low achievement motivation followed by medium $(35.00 \%)$ and high $(27.50 \%)$ achievement motivation. More than half of the jasmine growers $(52.50 \%)$ have high achievement motivation followed by medium $(32.50 \%)$ and low (15.00\%) achievement motivation. Among the crossandra growers, 42.50, 30.00 and 27.50 per cent belonged to high, low and medium achievement motivation category, respectively. Overall, about two-fifth $(43.33 \%)$ of the flower growers have high achievement motivation followed by medium $(29.16 \%)$ and low (27.50 \%).

Achievement motivation is more of a psychological variable which differs from individual to individual. It is assumed that achievement motivation forces the individual towards reaching the set goals. The reason behind two-fifth of the flower growers having high achievement motivation may be due to organizational efforts from all the family members to achieve the determined goal. The reason for low achievement motivation might be that flower growers had only middle school education, operating small size of land holding and their social and economic conditions might have not permitted them to have higher achievement orientation.

\section{Knowledge on farming enterprise}

The findings in Table 2 revealed that, 45.00 per cent of the chrysanthemum growers belonged to medium level of knowledge on farming enterprise followed by high $(35.00 \%)$ and low (20.00 \%) categories respectively. Among jasmine growers, 45.00 per cent of them belonged to medium level of knowledge about farming followed by low (42.50\%) and only 12.50 per cent belonged to high level of knowledge. About 45.83 per cent, 34.16 per cent and 20.00 per cent of the crossandra growers belonged to medium, low and high categories, respectively. Out of the total flower growers, 45.83 per cent belonged to medium level of knowledge on farming enterprise followed by low (34.16\%) and high (20.00\%). This could be attributed to their respective educational level, annual income, mass media exposure, extension participation and social participation of the Flower growers and their willingness to gather more information regarding improved agricultural practices.

\section{Risk orientation}

The results presented in Table 2 indicated that, more than one third $(35.00 \%)$ of the chrysanthemum growers belonged to medium risk orientation category. Whereas, equal percentage $(32.50 \%)$ of them belonged to low and high risk orientation category. It is revealed that, half $(50.00 \%)$ of the jasmine growers has low risk orientation followed by medium $(27.50 \%)$ and high $(22.50 \%)$. With respect to crossandra growers, 44.00 per cent, 42.00 per cent and 34.00 per cent belonged to medium, low and high risk orientation categories, respectively. At last, 36.66 per cent, 35.00 per cent and 28.33 per cent of the total flower growers belonged to medium, low and high risk orientation respectively. It concludes that, the flower growers take moderate risk in taking up any innovations. They don't practice all the new technologies and invest in the production. 
They would not like to follow the practices which involve certain degree of risks and uncertainties because of the fear of failure.

\section{Information seeking behaviour}

It could be inferred from Table 2 that, slightly less than half $(47.50 \%)$ of the chrysanthemum growers belonged to high information seeking behaviour category, whereas 32.50 per cent and 20.00 per cent of growers belonged to medium and low information seeking behaviour categories, respectively. Among jasmine growers, 37.50, 32.50 and 30.00 per cent of them belonged to high, medium and low information seeking categories respectively. Slightly less than half of the crossandra growers $(47.50 \%)$ had high information seeking behaviour followed by low $(27.50 \%)$ and medium $(25.00 \%)$ information seeking behaviour. On the whole, 44.16 per cent of the flower growers have high information seeking behaviour followed by medium $(30.00 \%)$ and low $(25.83 \%)$ information seeking behaviour. The plausible reasons for this trend might be due to their exposure to different interpersonal and mass media channels and obtaining consequent information helps them to acquire right information. As a result, the flowers growers will have an opportunity to improve their cognitions by getting recent and updated information from different sources.

\section{Ability to coordinate farm activities}

It is apparent from the Table 2 that, 45.00 per cent of the chrysanthemum growers belonged to medium level of ability to co-ordinate farm activities followed by low $(37.50 \%)$ and high $(17.50 \%)$ category. Further, 37.50, 35.00 and 27.50 per cent of the jasmine growers belonged to low, high and medium category of ability to co-ordinate farm activities, respectively. In case of crossandra growers, 45.00 per cent of them belonged to low category of ability to co-ordinate farm activities followed by medium (35.00\%) and high $(27.50 \%)$ categories, respectively. More than one-third $(37.50 \%)$ of the flower growers had low ability to co-ordinate the activities followed by medium (35.00\%) and high $(27.50 \%)$ ability to coordinate the activities. It was discouraging to note that nearly about one-third of the flower growers had low ability to co-ordinate farm activities. This can be enhanced by supplying farm inputs through co-operatives at reasonable price so that, they can procure the inputs at the right time.

\section{Economic motivation}

From Table 2 it is evident that, two fifth $(40.00 \%)$ of the chrysanthemum growers belonged to medium economic motivation category, whereas 30.00 per cent each of them belonged to low and high categories, respectively. Among jasmine growers, 42.50 per cent, 32.50 per cent and 25.00 per cent of growers belonged to medium, low and high economic motivation categories, respectively. Around two-fifth (42.50\% and $40.00 \%)$ of the crossandra growers show low and medium economic motivation respectively followed by high $(17.50 \%)$ economic motivation. Slightly less than half of the flower growers $(49.00 \%)$ belonged to medium economic motivation followed by low (42.00\%) and high $(29.00 \%)$ economic motivation. Unless one is not economically motivated, one cannot make sincere efforts and create interest in their profession. The possible reason might be that since, the flower cultivation involves high investment in order to get more profit and it is natural that, the flower growers should have high economic motivation. Other reason might be due to surrounding environment like neighbours, relatives, friends who were having medium standard of living and in addition low annual family income might be responsible for moderate economic motivation. Flower growers having high economic motivation were willing to take calculated risk for their 
field operations and were dare enough to invest capital on flower cultivation. Whereas, poor economic condition is due to poor credit orientation and small farms of flower growers and less exposure to modern agricultural technologies and the remedies for poor economic motivation could be achieved by improvement in their education level, financial incentives from co-operatives and banks and through proper guidance from their neighbour flower growers and extension professionals.

\section{Leadership ability}

The findings in Table 2 showed that, more than half $(55.00 \%)$ of the chrysanthemum growers had low level of leadership ability followed by medium $(25.00 \%)$ and high $(20.00 \%)$ level of leadership ability categories, respectively. Further, 42.50, 30.00 and 27.50 per cent of jasmine growers belonged to the categories of low, high and medium leadership ability, respectively. Among the crossandra growers, 42.50 per cent of them were found to possess low leadership ability followed by high (37.50 $\%)$ and medium leadership ability (20.00\%). On the whole, more than two-fifth $(46.66 \%)$ of the flower growers belonged to low leadership quality followed by high $(29.16 \%)$ and medium $(24.16 \%)$ leadership ability category. The flowers growers have low leadership quality as they have less exposure, less information and low co-ordinating ability. This could be overcome by enhancing their technical knowledge and developing leadership qualities by involving flower growers in training programmes, study tours and agricultural exhibitions.

\section{Scientific orientation}

It is observed from Table 2 that, two-fifth $(40.00 \%)$ of the chrysanthemum growers had medium level of scientific orientation followed by low $(37.50 \%)$ and high $(22.50 \%)$ scientific orientation, respectively. More than half of the jasmine growers $(52.50 \%)$ belonged to medium level of scientific orientation followed by high $(35.00 \%)$ and only 12.50 per cent belonged to low level of scientific orientation. More than three-fifth $(62.50 \%)$ of the crossandra growers comes under medium level of scientific orientation followed by high $(32.50 \%)$ scientific orientation. It is concluded that, slightly more than half $(51.66 \%)$ of the flower growers had medium scientific orientation followed by high $(30.00 \%)$ and only 18.33 per cent belonged to low scientific orientation. This indicates that the majority of the flower growers view the things scientifically with interest and good knowledge because of their higher education level, risk bearing ability, farming experience, social participation, mass media participation and extension system link. All these factors might have contributed for taking keen interest in scientific aspects in their farming activities.

Table.1 Overall entrepreneurial behaviour of flower growers

$\mathrm{N}=120$

\begin{tabular}{|c|c|c|c|c|c|c|c|c|c|c|}
\hline \multirow[t]{2}{*}{$\begin{array}{l}\text { Sl. } \\
\text { No. }\end{array}$} & \multirow[t]{2}{*}{ Category } & \multirow[t]{2}{*}{ Criteria } & \multicolumn{2}{|c|}{$\begin{array}{c}\text { Chrysanthemum } \\
\text { growers } \\
(n=40)\end{array}$} & \multicolumn{2}{|c|}{$\begin{array}{c}\text { Jasmine } \\
\text { growers } \\
(n=40)\end{array}$} & \multicolumn{2}{|c|}{$\begin{array}{l}\text { Crossandra } \\
\text { growers } \\
(n=40)\end{array}$} & \multicolumn{2}{|c|}{$\begin{array}{c}\text { Total } \\
(\mathbf{N}=120)\end{array}$} \\
\hline & & & $\mathbf{F}$ & $\%$ & $\mathbf{F}$ & $\%$ & $\mathbf{F}$ & $\%$ & $\mathbf{F}$ & $\%$ \\
\hline 1 & Low & $<151.55$ & 08 & 20.00 & 12 & 30.00 & 13 & 32.50 & 33 & 27.50 \\
\hline 2 & Medium & $151.55-159.42$ & 20 & 50.00 & 15 & 37.50 & 17 & 42.50 & 52 & 43.34 \\
\hline 3 & High & $>159.42$ & 12 & 30.00 & 13 & 32.50 & 10 & 25.00 & 35 & 29.16 \\
\hline
\end{tabular}


Table.2 Entrepreneurial behaviour component wise distribution of flower growers

\begin{tabular}{|c|c|c|c|c|c|c|c|c|c|c|}
\hline \multirow[t]{2}{*}{$\begin{array}{l}\text { Sl. } \\
\text { No. }\end{array}$} & \multirow[t]{2}{*}{ Components } & \multirow[t]{2}{*}{ Category } & \multicolumn{2}{|c|}{$\begin{array}{c}\text { Chrysanthem } \\
\text { um growers } \\
(n=40)\end{array}$} & \multicolumn{2}{|c|}{$\begin{array}{c}\text { Jasmine } \\
\text { growers } \\
(\mathrm{n}=40)\end{array}$} & \multicolumn{2}{|c|}{$\begin{array}{c}\text { Crossandra } \\
\text { growers } \\
(\mathbf{n}=\mathbf{4 0})\end{array}$} & \multicolumn{2}{|c|}{$\begin{array}{c}\text { Total } \\
(\mathbf{n}=\mathbf{1 2 0})\end{array}$} \\
\hline & & & $\mathbf{F}$ & $\%$ & $\mathbf{F}$ & $\%$ & $\mathbf{F}$ & $\%$ & $\mathbf{F}$ & $\%$ \\
\hline \multirow[t]{3}{*}{1} & \multirow{3}{*}{$\begin{array}{c}\text { Innovativeness } \\
\text { Mean- } 29.22 \\
\text { SD- } 04.88\end{array}$} & Low $(<26.77)$ & 12 & 30.00 & 09 & 22.50 & 19 & 47.50 & 40 & 33.33 \\
\hline & & Medium (26.77-31.65) & 13 & 32.50 & 13 & 32.50 & 11 & 27.50 & 37 & 30.83 \\
\hline & & High $(>31.65)$ & 15 & 37.50 & 18 & 45.00 & 10 & 25.00 & 43 & 35.83 \\
\hline \multirow[t]{3}{*}{2} & \multirow{3}{*}{$\begin{array}{c}\text { Decision making } \\
\text { ability } \\
\text { Mean- } 12.40 \\
\text { SD- } 01.57\end{array}$} & Low $(<11.61)$ & 07 & 17.50 & 13 & 32.50 & 15 & 37.50 & 35 & 29.16 \\
\hline & & Medium (11.61-13.18) & 19 & 47.50 & 16 & 40.00 & 18 & 45.00 & 53 & 44.16 \\
\hline & & High $(>13.18)$ & 14 & 35.00 & 11 & 27.50 & 07 & 17.50 & 32 & 26.66 \\
\hline \multirow[t]{3}{*}{3} & \multirow{3}{*}{$\begin{array}{c}\text { Achievement } \\
\text { motivation } \\
\text { Mean-13.14 } \\
\text { SD- } 01.89\end{array}$} & Low $(<12.19)$ & 15 & 37.50 & 06 & 15.00 & 12 & 30.00 & 33 & 27.50 \\
\hline & & Medium (12.19-14.08) & 11 & 27.50 & 13 & 32.50 & 11 & 27.50 & 35 & 29.16 \\
\hline & & High $(>14.08)$ & 14 & 35.00 & 21 & 52.50 & 17 & 42.50 & 52 & 43.33 \\
\hline \multirow[t]{3}{*}{4} & \multirow{3}{*}{$\begin{array}{c}\begin{array}{c}\text { Knowledge } \\
\text { about farming } \\
\text { enterprise }\end{array} \\
\text { Mean- } 09.22 \\
\text { SD- } 01.61\end{array}$} & $\operatorname{Low}(<8.40)$ & 08 & 20.00 & 17 & 42.50 & 16 & 40.00 & 41 & 34.16 \\
\hline & & Medium (8.40-10.02) & 18 & 45.00 & 18 & 45.00 & 19 & 47.50 & 55 & 45.83 \\
\hline & & High $(>10.02)$ & 14 & 35.00 & 05 & 12.50 & 05 & 12.50 & 24 & 20.00 \\
\hline \multirow[t]{3}{*}{5} & \multirow{3}{*}{$\begin{array}{c}\text { Risk orientation } \\
\text { Mean- } 09.22 \\
\text { SD- } 01.88\end{array}$} & Low $(<08.62)$ & 13 & 32.50 & 20 & 50.00 & 09 & 22.50 & 42 & 35.00 \\
\hline & & Medium (08.62-09.80) & 14 & 35.00 & 11 & 27.50 & 19 & 47.50 & 44 & 36.66 \\
\hline & & High $(>09.80)$ & 13 & 32.50 & 09 & 22.50 & 12 & 30.00 & 34 & 28.33 \\
\hline \multirow[t]{3}{*}{6} & \multirow{3}{*}{$\begin{array}{c}\text { Information } \\
\text { seeking } \\
\text { behaviour } \\
\text { Mean- } 28.92 \\
\text { SD- } 03.23\end{array}$} & Low $(<27.30)$ & 08 & 20.00 & 12 & 30.00 & 11 & 27.50 & 31 & 25.83 \\
\hline & & Medium (27.30-30.53) & 13 & 32.50 & 13 & 32.50 & 10 & 25.00 & 36 & 30.00 \\
\hline & & High $(>30.53)$ & 19 & 47.50 & 15 & 37.50 & 19 & 47.50 & 53 & 44.16 \\
\hline \multirow[t]{3}{*}{7} & \multirow{3}{*}{$\begin{array}{c}\text { Ability to } \\
\text { coordinate farm } \\
\text { activities } \\
\text { Mean-06.21 } \\
\text { SD- } 01.09\end{array}$} & Low $(<05.67)$ & 15 & 37.50 & 15 & 37.50 & 15 & 37.50 & 45 & 37.50 \\
\hline & & Medium(05.67-06.75) & 18 & 45.00 & 11 & 27.50 & 13 & 32.50 & 42 & 35.00 \\
\hline & & High $(>06.75)$ & 07 & 17.50 & 14 & 35.00 & 12 & 30.00 & 33 & 27.50 \\
\hline \multirow[t]{3}{*}{8} & \multirow{3}{*}{$\begin{array}{c}\text { Economic } \\
\text { motivation } \\
\text { Mean-18.15 } \\
\text { SD- } 01.73 \\
\end{array}$} & Low $(<17.28)$ & 12 & 30.00 & 13 & 32.50 & 17 & 42.50 & 42 & 35.00 \\
\hline & & Medium (17.28-19.01) & 16 & 40.00 & 17 & 42.50 & 16 & 40.00 & 49 & 40.83 \\
\hline & & High $(>19.01)$ & 12 & 30.00 & 10 & 25.00 & 07 & 17.50 & 29 & 24.16 \\
\hline \multirow[t]{3}{*}{9} & \multirow{3}{*}{$\begin{array}{c}\text { Leadership } \\
\text { ability } \\
\text { Mean-05.86 } \\
\text { SD- } 01.37\end{array}$} & Low $(<5.17)$ & 22 & 55.00 & 17 & 42.50 & 17 & 42.50 & 56 & 46.66 \\
\hline & & Medium (5.17-6.54) & 10 & 25.00 & 11 & 27.50 & 08 & 20.00 & 29 & 24.16 \\
\hline & & High $(>6.54)$ & 08 & 20.00 & 12 & 30.00 & 15 & 37.50 & 35 & 29.16 \\
\hline \multirow[t]{3}{*}{10} & & Low $(<7.99)$ & 15 & 37.50 & 05 & 12.50 & 02 & 05.00 & 22 & 18.33 \\
\hline & orientation & Medium (7.99-9.35) & 16 & 40.00 & 21 & 52.50 & 25 & 62.50 & 62 & 51.66 \\
\hline & $\begin{array}{c}\text { Mean-08.68 } \\
\text { SD- } 01.35\end{array}$ & High $(>9.35)$ & 09 & 22.50 & 14 & 35.00 & 13 & 32.50 & 36 & 30.00 \\
\hline 11 & Management & Low $(<13.73)$ & 13 & 32.50 & 11 & 27.50 & 12 & 30.00 & 36 & 30.00 \\
\hline & orientation & Medium (13.73-15.24) & 17 & 42.50 & 17 & 42.50 & 16 & 40.00 & 50 & 41.66 \\
\hline & $\begin{array}{c}\text { Mean-14.49 } \\
\text { SD- } 08.58\end{array}$ & High $(>15.24)$ & 10 & 25.00 & 12 & 30.00 & 12 & 30.00 & 34 & 28.33 \\
\hline
\end{tabular}

F- Frequency, \%- per cent

\section{Management orientation}

From the Table 2 it is found that, more than two-fifth $(42.50 \%)$ of the chrysanthemum growers had medium level of management orientation followed by low (32.50\%) and high $(25.00 \%)$ management orientation, respectively. Among the jasmine growers, 
$42.50,30.00$ and 27.50 per cent of them belonged to medium, high and low management orientation categories, respectively. Two-fifth of the crossandra growers $(40.00 \%)$ belonged to medium category followed by equal percentage $(30.00 \%)$ of them belonged to low and high management orientation. In total, 41.66 per cent of the flower growers belonged to medium management orientation followed by low $(30.00 \%)$ and high $(28.33 \%)$ management orientation. The probable reason for above trend may be that, field extension personnel of Department of Horticulture have interactions with flower growers to manage the production and marketing activities and to re-orient their level of management. The other plausible reason might be that the exposures of flower growers to various professional situations like extension meetings, field days, krishimelas etc. which might have activated the growers with the available resources like land, labour, and capital to attain higher yields in terms of profit.

In conclusion, the results indicated that less number of flower growers belongs to high entrepreneurial behaviour category. This calls for improvement of entrepreneurial behaviour of flower growers by organizing the effective and meaningful entrepreneurship development programmes by department of horticulture, KVK, NGO's in collaboration with the entrepreneurship development organizations like Centre for Entrepreneurship Development of Karnataka (CEDOK), Rural Development and Self Employment Training Institute (RUDSETI). It was also found that, significant percentage of them belongs to low category of ability to coordinate farm activities and leadership ability, medium category of decision making ability, knowledge on farming enterprise, risk orientation, economic motivation, scientific orientationand management orientation. Hence utmost concern should be given on improving the above qualities by conducting training, capacity building activities.

\section{References}

Anitha, B., 2004, A study on entrepreneurial behaviour and market participation of farmwomen in Bangalore rural district of Karnataka. M.Sc. (Agri.) Thesis (Unpub.), Univ. Agric. Sci., Bangalore.

Bhagyalaxmi, K., Gopalakrishna Rao, V. and Sudarshanreddy, M., 2003, Profile of the rural women micro-entrepreneurs. J. Res., 31 (4): 51-54.

Chandrapaul, K., 1998, A study on entrepreneurial behaviour of vegetable growers in Krishna district of Andhra Pradesh. M.Sc. (Agri.) Thesis, Acharya N. G. Ranga Agricultural University, Hyderabad.

Mahantesh Shirur, Ahlawat, O. P. and Manikandan, K., 2014, Profile characteristics and entrepreneurial attributes of trainees of National Training Programme on mushroom cultivation. Mushroom Res. 23 (1): 101-106.

Malivad Yogeshkumar Gulabsinh, 2016, entrepreneurial behaviour of vegetable growers in Navsari district. M.Sc. Thesis (Unpub.), Navsari Agric. Univ., Gujarat.

Naveenkumar, P., 2012, Entrepreneurial behaviour of pomegranate farmers in Chitradurga district of Karnataka. M.Sc. (Agri.) Thesis (Unpub.), Univ. Agric. Sci., Bangalore.

Rajendra Prasad, S., 2016, A study on entrepreneurial behaviour and economic performance of sugarcane growers in Chamarajnagar district of Karnataka. M.Sc. Thesis (Unpub.), Univ. Agric. Sci., Bangalore.

\section{How to cite this article:}

Bindu, N., Y.N. Shivalingaiah and Shwetha, N.V. 2019. Entrepreneurial Behaviour of Flower Growers in Tumkur District of Karnataka State. Int.J.Curr.Microbiol.App.Sci. 8(03): 656-663. doi: https://doi.org/10.20546/ijcmas.2019.803.081 